\title{
Truenos: ruidos, sonidos y modos de escucha en la creación sonora*
}

THUNDERS: NOISE, SOUNDS AND LISTENING MODES IN SOUND CREATION

TROVÕES: BARULHOS, SONS E MODOS DE ESCUTA NA CRIAÇÃO SONORA

\section{Carlos Mauricio Bejarano Calvo**}

Cuadernos de Música, Artes Visuales y Artes Escénicas

/ Volumen 12 - Número 2 / Julio - Diciembre de 2017

/ ISSN 1794-6670/ Bogotá, D.C., Colombia / pp. 187-209

Fecha de recepción: 31 de enero de 2017

Fecha de aceptación: 31 de mayo de 2017

Disponible en línea: 15 de septiembre 2017

doi:10.11144/Javeriana.mavae12-2.trsm

* Artículo de reflexión.

** Arquitecto por la Universidad Nacional de Colombia con estudios en creación en composición de música acusmática por el Institut National Audiovisuel, Groupe de Recherches Musicales (París). Artista sonoro. Investigador y creador en música concreta y arte sonoro. Profesor asociado en la Escuela de Artes Plásticas y director de la Maestría en Artes Plásticas y Visuales, Facultad de Artes, Universidad Nacional de Colombia, sede Bogotá. 


\section{Resumen}

A partir de una práctica artística personal con el sonido del trueno en los campos de la música concreta y el arte sonoro, este artículo presenta una interpretación libre en torno a este fenómeno atmosférico que acompaña a la humanidad a largo de su existencia. El trueno siempre ha estado presente en la vida cotidiana como un hecho contundente que marca drásticamente el paisaje. Es asociado a los poderes de la creación del mundo y en prácticamente todas las mitologías y religiones existen deidades portadores de sus poderes con diversos rituales que lo ponen en escena para reivindicar sus potenciales. En este artículo, se abordan ejemplos del campo del arte que han trabajado con el sonido del trueno, como el teatro, el arte sonoro y las músicas experimentales, y se exaltan el deseo y el gusto de crear y experimentar con esta compleja, potente y significativa materialidad sonora.

Palabras claves: trueno; ruido; silencio; arte sonoro; música concreta; artes plásticas

\section{Abstract}

From a personal artistic practice with the sound of thunder in the fields of concrete music and sound art this paper presents a free interpretation around this atmospheric phenomenon that accompanies humanity throughout it's existence. Thunder has always been present in everyday life as a stronge fact that dramatically marks the landscape. It is associated with the creation powers of the world, and in mostly all mythologies and religions there are deities carrying the powers of thunder with rituals that put it on the scene to claim it's potential. This text deals with examples from art that have worked with the sound of thunder, such as theater, sound art and experimental music, and stands out the desire and pleasure that is to create and experiment with this complex, powerful and significant sound materiality.

Keywords: thunder; noise; silence; sound art; concrete music; arts

\section{Resumo}

A partir de uma prática artística pessoal com o som de um trovão nos campos da música concreta e a arte sonora este texto apresenta uma interpretação livre em torno deste fenômeno atmosférico que acompanha a humanidade ao longo da sua existência. O trovão sempre tem estado presente na vida cotidiana como um fato contundente que marca de maneira dramática a paisagem. O trovão tem sido associado aos poderes da criação do mundo e em quase todas as mitologias e religiões existem deidades portadoras dos seus poderes com diversos rituais que colocam-no na cena para reivindicar seus potenciais. Neste texto abordamse exemplos do campo da arte que tem trabalhado com o som do trovão como o teatro, a arte sonora e as músicas experimentais e exalta-se o desejo e o gosto de criar e experimentar com a complexa, potente e significativa materialidade sonora.

Palavras chave: trovão; barulho; silêncio; arte sonora; musica concreta; artes plásticas 


\section{TRUENO}

Como la erupción de un volcán celeste, como el resonar de un enorme tambor atmosférico, el trueno parece condensar el ruido primigenio de la creación y la energía sonora máxima y esencial de la naturaleza. El trueno es esa tensión generativa que apareció en el inicio de la vida y que aún persiste en el mundo, como la protopoiesis original en la cual se expresa la poderosa capacidad productiva, creadora y fabricante de la naturaleza. El trueno expresa y encarna el retumbar de un mundo oculto y, cuando lo escuchamos a lo lejos en el horizonte, parece que surgiera de las mismas entrañas de la tierra.

Un sonido producido por el Cielo es un acto creador, que sólo alcanzará el grado más alto de realidad física después de haberse transformado en la tierra en un retumbo. La realidad del Cielo es una creación de la Tierra, y la realidad de la Tierra es una creación del Cielo.

(Andrés 2012, 1608)

El trueno ha acompañado nuestra vida desde tiempos inmemoriales, desde el más remoto pasado siempre ha estado presente, potente y amenazante, en cualquier lugar y resquicio del planeta, en cualquier momento o instante de la cotidianidad. Él anuncia los posibles cambios atmosféricos, avisa la aparición de una tormenta o un aguacero, marca periodos climáticos o épocas para el cultivo y la agricultura, pero, por sobre todas las cosas, es la voz de los dioses... Con su perturbadora presencia ha anunciado y mantenido a lo largo de las épocas y a lo ancho de las geografías los grandes poderes de dioses celestes, creadores, dioses del trueno íntimamente ligados a los cielos y las aguas, a los climas, a la lluvia y los aguaceros, a la fertilidad, a los vientos, a las tormentas y a los rayos. Desde tiempos remotos hemos imitado, sobre todo mediante la percusión de tambores, el sonido del trueno para llamar la lluvia.

El trueno es una consecuencia sonora después de que se produce un rayo. El rayo es un fenómeno que se origina en las nubes de tipo cumulonimbos; estas son densas y potentes, de dimensión vertical, que pueden ir de 2 a $20 \mathrm{~km}$. El rayo se produce entre dos nubes o entre una nube y la tierra. En el interior de la nube, se crean zonas de carga eléctrica positivas (arriba) y negativas (abajo) con una gran diferencia de potencial entre estas (hasta de $100 \mathrm{mi}$ llones de voltios). Estos campos eléctricos son generados por la fricción entre gotas de agua, unas congeladas (granizo) que tienden a caer y otras de vapor que tienden a subir, y se da entre estas una transferencia de carga (el rayo propiamente dicho). Dentro de la misma nube o en relación con la tierra - como otro polo positivo-, se forma un condensador de placas paralelas que genera una avalancha de electrones en forma de columna que desciende escaIonadamente a una velocidad de $105 \mathrm{~m} / \mathrm{s}$. Este fenómeno, además de generar el resplandor propio del rayo, calienta el aire a $30000{ }^{\circ} \mathrm{C}$ y, al expandirse a gran velocidad y mezclarse con el aire frío, se contrae y produce un poderoso chasquido inicial. Se genera así una serie de ondas de choque que son las responsables del ruido del trueno y que se van expandiendo y contrayendo perdiendo paulatinamente energía e intensidad. Estas ondas de choque viajan a una velocidad de propagación de 12 a $14 \mathrm{~km} / \mathrm{s}$ (y no a $340 \mathrm{~m} / \mathrm{s}$ como lo sería la velocidad de las ondas acústicas normales en el aire). Dependiendo de la naturaleza de este fenómeno y de la distancia y ubicación de la persona que lo escucha, el sonido puede variar desde un marcado y fuerte crujido hasta un largo y lejano estruendo; en ocasiones, puede alcanzar intensidades 
de hasta $110 \mathrm{~dB}$, cercano al umbral de dolor para el oído humano. “El trueno se forma entre las irregularidades de las nubes y sus cavidades, lo cual genera 'ruidos de todas clases', [...] estrépitos semejantes a los que vienen del interior terrestre, que es cuando se producen los seísmos" (Andrés 2012, 1604).

Desde una perspectiva puramente morfológica, el sonido del trueno contiene una enorme y compleja masa espectral, es un potente fragor resonante lleno de textura y rugosidades; en general, nace con un fuertísimo ataque con el máximo contenido armónico posible y tiene una amplia expansión y un largo desarrollo espacio-temporal. Durante este transcurso dinámico, la masa se va adelgazando gradualmente, las frecuencias se van afilando, su intensidad se va desvaneciendo y extinguiendo a medida que el sonido se proyecta en el espacio llenando los intersticios y afectándose con las características de este, como la reverberación, la reflexión o la resonancia, propias del enorme y variado escenario o territorio físico y geográfico donde habita y se propaga.

¿Cómo podemos disponer del sonido de un trueno? ¿Cómo tenerlo a la mano para su uso? ¿Tenemos acaso la capacidad de crearlo... o al menos recrearlo?

\section{“TRES SONIDOS”}

En la pieza musical Tres sonidos (Bejarano 2013) para percusión y electrónica en vivo, la intensidad, la masa y la densidad bordean la noción de ruido en toda su dimensión material, textural, granulométrica y física. La pieza consta de tres secciones o movimientos, estos tres sonidos son realmente tres truenos, cada uno de ellos con unas cualidades morfológicas diferentes. El primero nace con un ataque violento, denso y rugoso con una amplia masa (contenido espectral o armónico), y en su interior se genera una agitación permanente de partículas, que se va diluyendo, ralentizando y desvaneciendo a lo largo de su duración hasta descansar llegando a un silencio elocuente. El segundo es una especie de trueno muy lejano y sutil que va apareciendo gradualmente, con una masa espectral que resalta la franja de los graves y con un carácter liso y transparente, casi sin accidentes en su interior; también se desvanece hasta llegar a otro silencio. El tercer sonido se desarrolla como un trueno al revés, invertido temporalmente, partiendo desde un bajísimo nivel de intensidad y con poca masa va creciendo hasta llegar a un clímax de altísima y máxima densidad, intensidad y contenido espectral, finalizando con un recorte súbito, abrupto y abismal. El gesto interpretativo y la instrumentación ponen el énfasis en la percepción del ruido y del silencio que se encuentran en sus características conceptuales y perceptivas más dramáticas y extremas. Densidad, masa, textura y dinámica desempeñan un papel fundamental en el desarrollo de estos tres complejos sonidos truenos. 


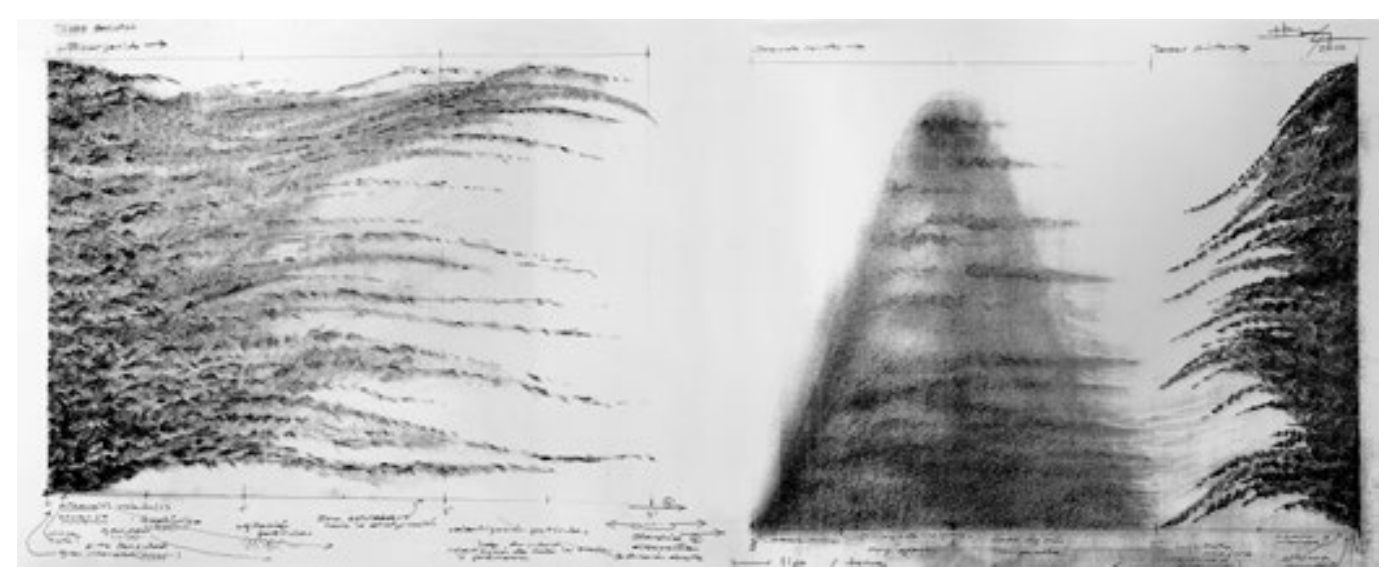

Figura 1. Carlos Mauricio Bejarano Calvo: Grafía (partitura gráfica) de Tres sonidos, 2013.

\section{DIOSES}

Los responsables del trueno y las tormentas constituyen un enorme repertorio de deidades que están presentes en prácticamente todas las culturas. Estas deidades son ambiguas y ambivalentes, pues portan a la vez el potencial de la destrucción y la muerte, así como el poder de la vida, la creación y la fertilidad. En las diversas mitologías, el trueno ha sido imaginado como el bramido de un toro divino, como el batir de alas de un pájaro gigante, como el rugido de un jaguar mágico, como el retumbo de las ruedas de un gran carruaje o como el estrépito de una máquina celestial.

Illapa en las alturas de los andes peruanos; Tláloc en las planicies centrales mexicanas con sus bosques de coníferas, selvas, desiertos rocosos y manglares; Chac en las selvas tropicales mesoamericanas; Taranis en la diversidad de bosques europeos; Ishkur en los valles fértiles del cercano oriente; Thor en los fríos bosques nórdicos; Susanoo y Aji-Suki-Taka-Hi-Kone en los recónditos intersticios del archipiélago de las orientales islas montañosas; LeiTsu y su ayudante el tamborilero contador de rayos Lei Kung en los extensos territorios de la China continental; y Júpiter y Zeus en las estribaciones tormentosas de la geografía mediterránea.

Brahma, en el hinduismo, ostenta el poder del trueno como sonido primordial; Dharma es la manifestación de la verdad, su elemento es el éter y su sonido interior es el trueno; Adad (en acadio), Ishkur (en sumerio) y Hadad (en arameo y árabe) son los dioses semitas poderosos regentes de las tormentas y las lluvias; Enlil en la mitología sumeria es el dios del cielo, del viento, las tempestades y la respiración; Umu, demonio babilónico creado por Tiamat mueve y controla las tormentas; Odei, que en euskera significa 'nube', es el genio que provoca los truenos, los relámpagos y las tormentas en la mitología vasca; Perkunas, es el dios eslavo del trueno y de los meteoros y en su nombre está la raíz per que significa 'percutir', 'golpear'. Todos estos dioses del trueno están siempre íntimamente ligados a los cielos y las aguas, a los climas, a la lluvia y los aguaceros, a los vientos, las tormentas y los rayos.

Juya, en la cultura wayuu, como dios supremo es el encargado de la fecundidad de la tierra y de que la vida emane de sus entrañas... es el dios de la abundancia; como forma de agradecimiento, se le evoca mediante las danzas tradicionales llamadas Yonna y Kaaulayawaa, las cuales son presididas por los sonidos expansivos de la Kaasha (tambora wayuu), a cuya resonancia, similar al retumbar de los truenos, se le atribuyen efectos mágicos para atraer o aligerar la presencia de lluvias sobre la tierra. 
Si el gusano de seda denominara cielo a la pelusilla que forma su capullo, razonaría igual que lo hicieron los antiguos dando a la atmósfera el nombre de cielo, que es, [...] la seda de nuestro capullo. Los antiguos creyeron que los vapores que exhalan los mares y la tierra y que forman las nubes, los meteoros y los truenos, eran la morada de los dioses. (Voltaire, 1764)

Tal vez, pretendiendo ser, o por lo menos simularlo, como demiurgos primigenios y arcaicos, podemos crear un trueno, a imagen y semejanza de algunas deidades que a lo ancho del mundo y a lo largo de la historia lo han hecho. ¡Asir y aprehender el fragor del trueno, inventar y construir instrumentos o dispositivos que truenen! Tronadores...

\section{TAMBOR}

El tambor ha sido el instrumento más antiguo y básico en ser utilizado para la reproducción sonora de truenos y tormentas. El tambor, con su carácter ruidoso, telúrico y mágico, ha sido asociado con los dioses de la creación del universo y expresa y representa el ciclo cósmico, el ritmo del mundo y el pulso de la naturaleza. Se le asocia estrechamente al trueno y la tormenta y su potente y espléndida sonoridad es utilizada en rituales, sacrificios, ceremonias y cultos funerarios y dionisiacos, danzas de la muerte, místicas o demoniacas, ritos lunares y de liberación espiritual, ofrendas de fertilidad y creación, ritos iniciáticos, acciones bélicas y paradas militares.

En muchas de las celebraciones cristianas de Semana Santa, realizadas en España, el tambor es uno de los instrumentos con mayor protagonismo, tan es así que existe hoy en día la ruta del tambor y el bombo en Aragón. Estas tradiciones vienen desde la Edad Media y, por ejemplo, en muchos pueblos de esta comunidad autónoma, como el famoso caso de Calanda en la provincia de Teruel, se realiza la tamborada que comienza con la rompida de la hora. Una gran cantidad de tamboreros se concentran en la plaza del Ayuntamiento al mediodía del jueves y generan un gran ruido con un multitudinario toque de tambores que dura ininterrumpidamente hasta el mediodía del viernes. Además, se realizan otras tamboradas con la procesión del pregón, la procesión de la soledad y la procesión del entierro del sábado.

Una de las experiencias sonoras más extraordinarias es la tamborada de Hellín (conocida también como la ciudad del tambor), en la provincia de Albacete, en la región de Castilla-La Mancha. Esta se realiza con el redoble de unos veinte mil tambores (la mayor concentración de este instrumento en el mundo). Durante la Semana Santa, este rito ancestral del tambor se presenta como una manifestación ambigua entre religiosidad y festividad pagana en su máxima expresión. Ataviados con túnicas negras, los participantes redoblan desde el mediodía del jueves toda la noche sin descansar hasta el día siguiente, cuando se recoge la procesión al mediodía. Este estruendo atronador puede escucharse a varios kilómetros de distancia.

En la tradición cristiana, el tambor tiene un valor simbólico como intermediario entre el cielo y la tierra. La piel del tambor, la membrana (la carne), se estira sobre la caja como si fuese el acto de la crucifixión del Hijo de Dios que representa una especie de altar para el sacrificio. El tambor es como una barca espiritual que permite pasar del mundo visible al invisible, y es un umbral, una interfaz, un límite topográfico que separa y une el cielo y la tierra y la tierra con el infierno. 


\section{TRONADORES}

En el teatro del barroco en el siglo XVI, en el interior de esa maravillosa caja negra, de ese espacio de la ilusión, la representación dramatúrgica requería instalar algunos sonidos reales del entorno, entre estos, fueron muy importantes los sonidos del viento, la lluvia, la tormenta, la tempestad y el terremoto. En las puestas en escena, se recurre, entonces, al valor sinecdótico del ruido. Y, para lograr la presencia del trueno en el escenario, se utilizaron en las primeras representaciones los efectos pirotécnicos consistentes en una larga traca o tronador, un artificio de pólvora que se hacía con una serie de petardos colocados a lo largo de una cuerda y que estallaban sucesivamente; también fue utilizada una técnica muy senciIla haciendo rodar una gruesa y pesada bola de piedra sobre el entarimado de madera del escenario. Con la evolución de la escenografía y la tramoya —la máquina teatral en sí- en los siglos XVII y XVIII, este ruido fue generado por las caxas de trueno: una bola se ponía a rodar por un canal con peldaños de desigual tamaño. En esta evolución de la tramoya, surgen varias máquinas sonoras para poner en escena los rumores de las tormentas. Aparecen, entonces, aparatos como la chapa de tormenta, una plancha de metal para imitar los rumores de la tormenta, cuyo sonido se consigue cimbreando una plancha de latón. La cabría de truenos es una máquina para imitar el chasquido o estallido del trueno que se produce soltando una soga de la que cuelga una serie de chapas metálicas - o de madera-golpeándose cada una de ellas progresivamente una sobre otra. También se construyó el barril de truenos para imitar el sonido de los truenos, inspirado en una acotación de Miguel de Cervantes en su tragedia Numancia: "al girar los cantos de río se golpean entre sí y sobre las paredes interiores del barril". Pudo haberse usado montando el barril sobre un soporte pero también rodando el barril directamente sobre el escenario. Otro dispositivo fue el carretón de truenos, un carro con ruedas dentadas que, al desplazarse sobre el piso, generaba el sonido del trueno. De la misma manera, la tabla de truenos con ruedas irregulares se ponía a rodar sobre la superficie del tablado (de forma que el foso actuara como caja de resonancia). Otra variante fue la vagoneta de truenos que fue la máquina rodante más completa y efectiva en su categoría; un cajón lleno de piedras se arrastra por la superficie de las galerías de trabajo del escenario o por el mismo tablado. Por último, es importante reseñar la carraca o matraca múltiple, máquina circular con ocho lengüetas y cuatro matracas, utilizada con gran eficacia para representar el sonido de terremotos, truenos, guerras y grandes estruendos; este último instrumento combina los martilletes móviles de madera con las lengüetas percutidas por una rueda dentada, y además de utilizarse en estos espectáculos teatrales, cumplía una función litúrgica durante las celebraciones religiosas de Semana Santa.

Así como el tambor, pareciera que el trueno tiene esa doble dimensión inalcanzable... a la vez celestial y trascendente, como física, matérica y pura potencia energética; habita el día a día de nuestras vidas y llena el paisaje con sus estruendos y estrépitos, nos acompaña, nos rodea, nos cobija, nos aterra y siempre nos advierte. El trueno es un sonido ordinario a veces olvidado, cotidiano y común, pero siempre que irrumpe en el horizonte nos maravilla y nos sorprende. "Todo lo que es tormentoso trasciende el ruido ordinario de la existencia congruente, resonando en las capas profundas de la memoria como cascos imponentes, cánones bélicos, aplausos sublimes" (Ronnberg y Martin 2011, 68). 


\section{SONIDO OBJETO}

El trueno como sonido, como un objeto sonoro (Schaeffer) en sí mismo, como un sonido objeto, merece y requiere ser valorado y mantenerse como una materialidad en permanente emergencia y total disponibilidad. En el marco particular de la música concreta y de una de sus condiciones fundacionales y esenciales como es la sonofijación (fijación o registro de un sonido en un soporte o medio), entendemos por objeto sonoro todo fenómeno o evento sonoro percibido como un todo coherente. Y lo que es igual, este sonido objeto es percibido como una unidad en su materialidad, su textura y respecto de sus cualidades y características morfológicas propias. Los sonidos objeto son entes catalogables en una especie de botánica, coleccionables, con límites espacio-temporales claros y definidos, como elementos terminados que poseen un principio y un fin, conjugables y constituyentes de un archivo, de un paisaje. A estos sonidos objeto les añadimos atributos y los acompañamos de sustantivos y adjetivos, nominándolos, clasificándolos, caracterizándolos y cualificándolos.

El sonido como objeto lo estabilizamos deteniendo el tiempo; lo estudiamos y observamos al micrófono; le hemos hecho una rigurosa taxonomía, lo fijamos y memorizamos y lo tenemos totalmente disponible. Pero este objeto siempre necesita ser proyectado... pasar de ser un sonido objeto a un sonido imagen (Bayle). Es como si sacáramos de nuestro archivo, de nuestro almacén o refrigerador de conservas, las crisálidas en el punto preciso para ser mariposas, desplegarlas en el espacio, proyectar la imagen. Pasamos de un acto fonográfico (fijación o registro) a una acción cinematofónica (proyección o interpretación); vamos de una escucha reducida del sonido objeto a una escucha revelada de la imagen sonora. En primera instancia, fijamos el sonido en soportes y detenemos el tiempo, ahora proyectamos las imágenes sonoras en el espacio de escucha y liberamos de nuevo el tiempo.

Cuando asumimos y trabajamos con el sonido, con los sonidos objeto, con el trueno por ejemplo, como una materialidad disponible, plástica o musical, realizamos un acto esencialmente poiético. Transformamos actos e ideas en sonidos, sonidos en sonidos, silencios en sonidos, sonidos en silencios, sonidos en ruidos, ruidos en sonidos y gestos en truenos, estruendos y estrépitos. Estas acciones aspiran a ser realizadas por seres humanos ordinarios que intentan, como un acto imposible, ser auténticos foniurgos, asumiendo la creación del sonido, en este caso el sonido del trueno, en pleno sentido. Más allá de la producción técnica o artística del sonido del trueno, este acto deberá implicarse en él mismo, en sí mismo, en nosotros mismos, como una acción que nace desde sí, que emerge, que se despliega... ser trueno.

¿Acaso somos capaces en un acto poiético de crear el trueno, de convertir esta circundancia en un acto circunstancial que se hace sonido, materia y acto intencional?

Desde hace veinticinco siglos el saber occidental intenta ver el mundo. Todavía no ha comprendido que el mundo no se mira, se oye. No se lee, se escucha (Attali 1996, 11). 


\section{TRUENO OBJETO}

En los albores del siglo XX, el artista Luigi Russolo con la invención de sus instrumentos ruidosos, entre los cuales estaba un tronador, y el escritor James Joyce con su onomatopeya de cien letras, hicieron del sonido del trueno un objeto disponible. Como ya lo hemos mencionado, en las más antiguas tradiciones mitológicas y religiosas, siempre ha estado presente el trueno, muy ligado al tambor, como símbolo del sonido primordial que da origen a todo.

"¡bababadalgharaghtakamminarronnkonnbronntonnerronnntuonnthunntrovarrhounawnskawntoohoohoordenenthurnuk!" (Joyce 1993, 17).

En estas primeras décadas del siglo pasado, algunas de las vanguardias artísticas, como el futurismo, el proyeccionismo, el estridentismo y el dadaísmo, entre otras, proponen, dentro de sus diversas búsquedas, un serio y profundo compromiso con el sonido como una nueva materialidad asumiéndolo como entidad en sí misma con fuertes potenciales expresivos y valores estéticos, que desafían el silencio, los ideales de la armonía y del orden del mundo, enfrentándose y asumiendo el ruido con vehemencia, intensidad y cierto radicalismo. La poesía, la música, el cine y las artes plásticas descubren y re-inventan el sonido y se permean y contaminan con el ruido, se desplazan de un territorio conocido y cómodo hacia terrenos inauditos, experimentales, riesgosos y ruidosos... y se hacen permeables a las estridencias de las máquinas y a los rumores de la vida, a los ruidos de los dispositivos tecnológicos y su velocidad y a los estertores de la naturaleza y de la voz humana y su expresión onomatopéyica y ruidosa.

Se suscita, entonces, un rompimiento radical con la tradición musical, literaria y artística que incorpora el ruido como parte esencial de sus lenguajes, de sus gramáticas. El ruido en su máxima crudeza y en toda su dimensión y potencia ambiental, instrumental, material, musical, simbólica, plástica, industrial y cotidiana. Nace un nuevo arte de los ruidos, donde se promulga la necesidad de tener una escucha más amplia y atenta y conquistar la variedad infinita de sonidos ruidos...

\footnotetext{
Hay que romper este círculo restringido de sonidos puros y conquistar la variedad infinita de sonidos-ruidos. [...] Disfrutamos mucho más combinando idealmente los ruidos de tren, de motores de explosión, de carrozas y de muchedumbres vociferantes. [...] Atravesemos una gran capital moderna, con las orejas más atentas que los ojos, y disfrutemos distinguiendo los reflujos de agua, de aire o de gas en los tubos metálicos, el rugido de los motores que bufan y pulsan con una animalidad indiscutible, el palpitar de las válvulas, el vaivén de los pistones, las estridencias de las sierras mecánicas, los saltos del tranvía sobre los rieles, el restallar de las fustas, el tremolar de los toldos y las banderas. Nos divertiremos orquestando idealmente juntos el estruendo de las persianas de las tiendas, las sacudidas de las puertas, el rumor y el pataleo de las multitudes, los diferentes bullicios de las estaciones, de las fraguas, de las hilanderías, de las tipografías, de las centrales eléctricas y de los ferrocarriles subterráneos. (Russolo 1998, 9, 10)
}

Russolo escribe en 1913 el Arte de los ruidos, en el cual propone una valoración positiva y un acercamiento creativo al ruido. La escucha amplía sus horizontes perceptivos a la totalidad sonora del mundo. 
He aquí las seis familias de ruidos de la orquesta futurista que pronto llevaremos a la práctica mecánicamente: 1. Estruendos, truenos, explosiones, borboteos, baques y bramidos. 2. Silbidos, pitidos y bufidos. 3. Susurros, murmullos, refunfuños, rumores, gorgoteos. 4. Estridencias, chirridos, crujidos, zumbidos, crepitaciones y fricaciones. 5. Ruidos obtenidos a percusión sobre metales, maderas, pieles, piedras, terracotas, etc. 6. Voces de animales y de hombres: gritos, chillidos, gemidos, alaridos, aullidos, risotadas y estertores. (Russolo 1998, 14)

Poniendo en la práctica sus reflexiones, Russolo inventa y construye los entonarruidos, una serie de instrumentos musicales mecánicos dispuestos orquestalmente para entonar los ruidos: aulladores, estruendores, crepitadores, frotadores, explotadores, gorgoteadores, zumbadores, tronadores y silbadores, entre otros. Estos nuevos instrumentos fueron construidos según cajas metálicas con un diafragma y una trompa y en su interior con una cuerda metálica que se podía tensar manualmente para variar el tono, además de un mecanismo con manivela que actuaba sobre un dispositivo giratorio que rozaba la cuerda y generaba así el sonido característico de cada uno de los instrumentos.

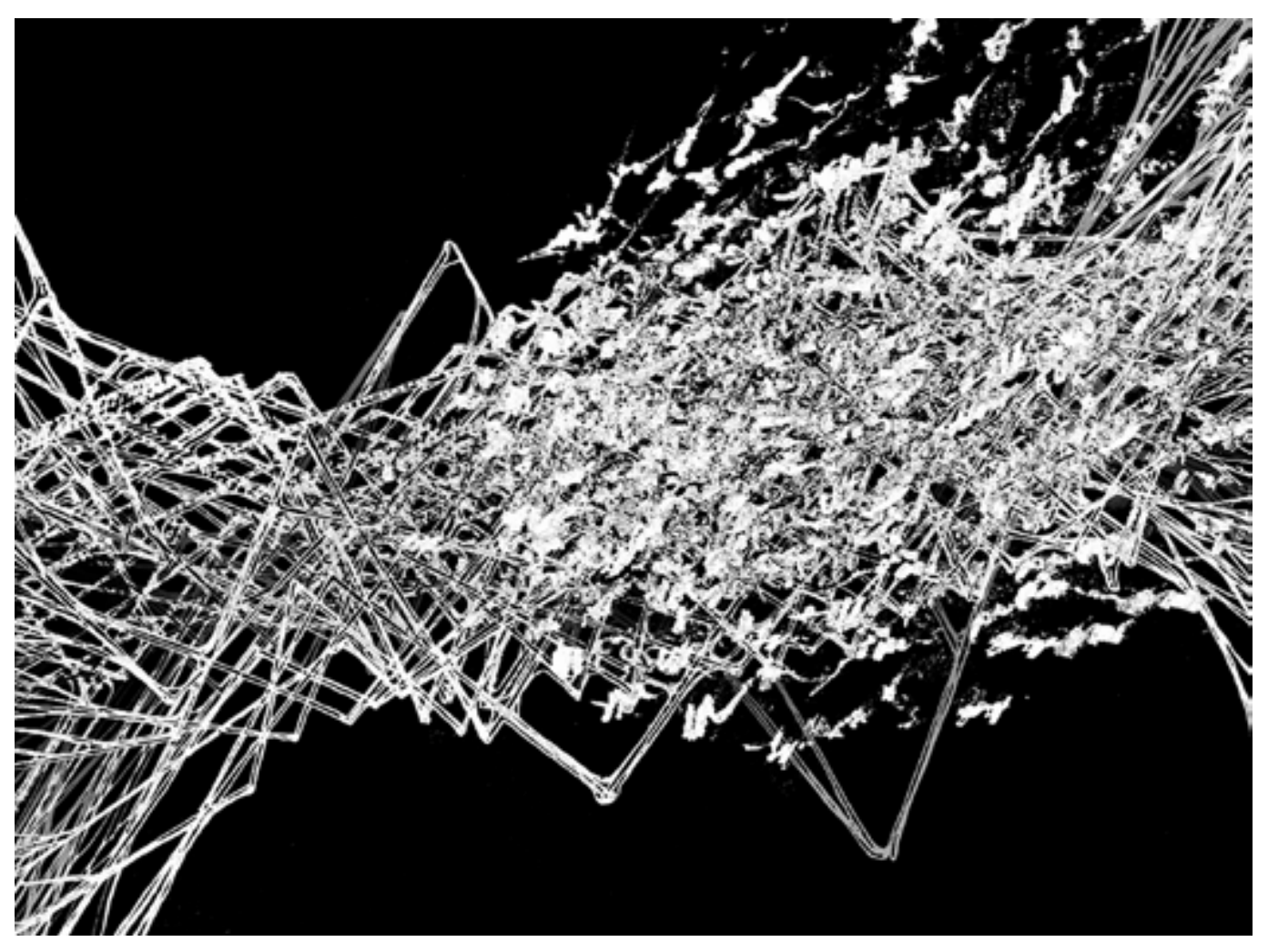

Figura 2. Carlos Mauricio Bejarano Calvo: Grafía de un estruendo.

Para convencerse de la sorprendente variedad de ruidos basta con pensar en el fragor del trueno, en los silbidos del viento, en el borboteo de la cascada, en el gorgoteo de un río, en el crepitar de las hojas, en el trote de un caballo que se aleja, en los sobresaltos vacilantes de un carro sobre el empedrado y en la respiración amplia, solemne y blanca de una ciudad nocturna; en todos los ruidos que emiten las fieras y los animales domésticos y en todos los que puede producir la boca del hombre sin hablar y cantar. (Russolo 1998, 13) 


\section{ESTRUENDOS Y ESTRÉPITOS}

Con el ruido nació el desorden y su contrario: el mundo. Con la música nació el poder y su contrario: la subversión.

Attali (1996, 15)

Tal vez lo que pudo ser un gran trueno, un estruendo verdaderamente extraordinario que irrumpió y alteró por completo el paisaje, la escucha y la vida de los ciudadanos del común, se escuchó a finales del siglo XVII en Santafé. El denominado tiempos del ruido es sin duda el acontecimiento más ruidoso que persiste en el imaginario de los bogotanos. Este acontecimiento histórico aún suena en nuestra memoria colectiva.

Los tiempos del ruido fue un evento ocurrido en Santafé en 1687, un domingo 9 de marzo a las diez de la noche, cuando "un extraño y ensordecedor ruido" se escuchó durante quince minutos y causó pánico en los pobladores que a esa hora dormían tranquilamente. La primera crónica de este extraordinario evento fue escrita por el sacerdote jesuita Pedro de Mercado en 1691. En tal crónica, se nombra este evento como "un portentoso ruido escuchado en Santafé con el cual muchos despertaron para mejorar su vida". Se habla de este gran ruido como un horroroso estrépito, como un estruendo horrible y aterrador que se escuchó a gran distancia en la ciudad de Santafé y en las ciudades circunvecinas. Los pobladores imaginaron que la llanura bramaba, los montes crujían o los vientos chocaban violentamente entre sí. Muchos aseguraron haber oído tambores dando la señal de combate y que este estruendo correspondía a las máquinas de guerra, a los gritos de soldados que marchan con las banderas al aire y al estrépito que hacen al sacar los sables para el combate. Se decía del estruendo que era una desordenada mezcla de los elementos como si el éter se hubiera resquebrajado. El ruido parecía ser como el que producen las carretas por los empedrados, haladas por caballos desbocados, como el que suelen producir descomunales troncos al ser arrastrados por las plazas de las calles pavimentadas con piedras desiguales o como un torrente que, deslizándose hacia abajo entre peñas, aumentado su caudal e impaciente de su cauce, se desparrama furioso por los campos y consigo arrastra árboles arrancados de los montes, que llenan el aire de estruendo y horrible fragor entre los precipicios y remolinos. El estrépito parecía como si por leguas rodasen en las entrañas de la tierra máquinas de inimaginable peso.

La sociedad santafereña quedó tan consternada que durante mucho tiempo cada 9 de marzo se realizaba un acto público en muchas iglesias del centro, y particularmente en la iglesia de La Candelaria, ubicada en la esquina entre la calle de La Candelaria (calle 11) y la calle de La Paz (carrera 4). En esta conmemoración, se descubría el santísimo sacramento durante toda la tarde hasta las 10 de la noche, coincidiendo con la hora en la que había comenzado el gran ruido en esa noche santafereña, y que dio origen años después a la expresión tiempos del ruido, con la cual los bogotanos nos referimos a las cosas o hechos ocurridos tiempo atrás. 


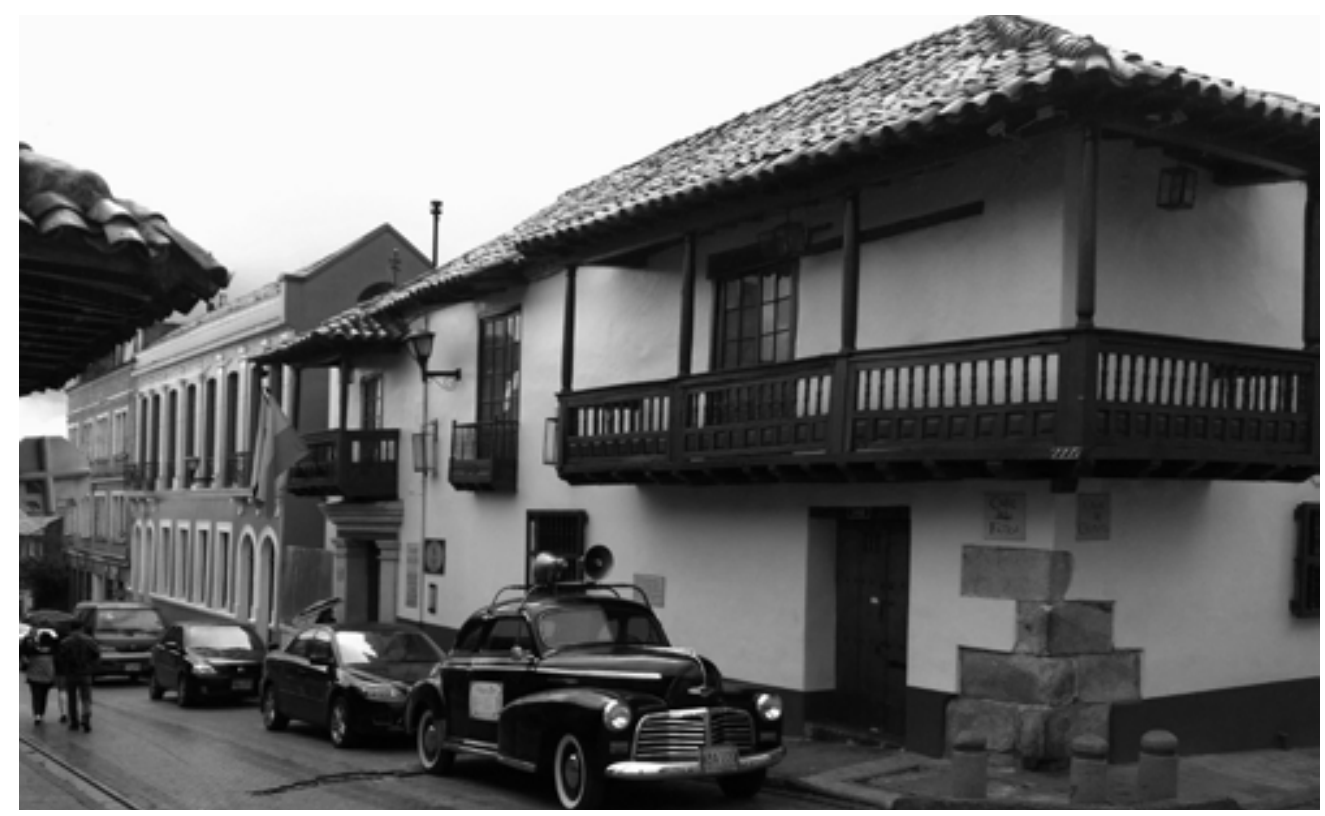

Figura 3. Carlos Mauricio Bejarano Calvo: Estruendo, 2012.

Sorprendentemente, hace algunos años fueron encontrados fragmentos de una grabación fonográfica original de esta efemérides histórica, junto con una curiosa máquina y algunos manuscritos. Estos documentos pertenecieron a don Francisco Chirinola y Calvo, quien en su época y latitud era un adelantado científico e inventor precoz. Don Paco, como se le conocía en Santafé, dentro de sus múltiples investigaciones, había inventado un extraordinario aparato al que podríamos llamar hoy en día protofonógrafo. Él lo denominó libro parlante y lo describió como

al abrir la caja, hallé dentro un no sé qué de metal muy semejante a nuestros relojes, lleno de un sinfín de pequeños resortes y máquinas imperceptibles. Es ciertamente un libro, pero libro maravilloso, sin hojas ni letras; libro es, en fin, en el que, para comprender, los ojos son inútiles y no se necesitan más que orejas. Cuando alguien, pues, desea leer [registrar un ambiente sonoro], da cuerda con una gran cantidad de llaves de todas clases a esta máquina, coloca luego la aguja sobre el capítulo que desea escuchar y al mismo tiempo salen de esta nuez, como boca de hombre o de instrumento musical, un disco mecánico de metal y los sonidos quedaban consignados en su interior. Luego, para escucharlos, colocaba de nuevo la aguja en el capítulo grabado que deseaba escuchar y al mismo tiempo salen de esta nuez, como la boca de hombre o instrumento musical, todos los sonidos distintos y diferentes. (Bergerac 1987, 144)

Este dispositivo, acompañado de otras grabaciones y un conjunto de documentos escritos, fue encontrado durante el reciente proceso de restauración en la casa llamada de La Independencia o Casa de la Urnas, que se encuentra en el costado sur de la calle de la Fatiga (calle 10), entre la calle de Santa Librada (carrera 3) y la calle de la Patria (carrera 4). Se trata de una antigua casa colonial, posiblemente construida en 1637, de dos pisos, originalmente con más de treinta y ocho habitaciones, varios balcones y cuatro patios. Hoy en día funciona allí Z'otz, museo sonoro, especie de gabinete de soluciones sonoras imaginarias; un museo con un carácter único y particular, dedicado a coleccionar sonidos, artefactos, aparatos y eventos sonoros extraordinarios, muchos de ellos imposibles. 


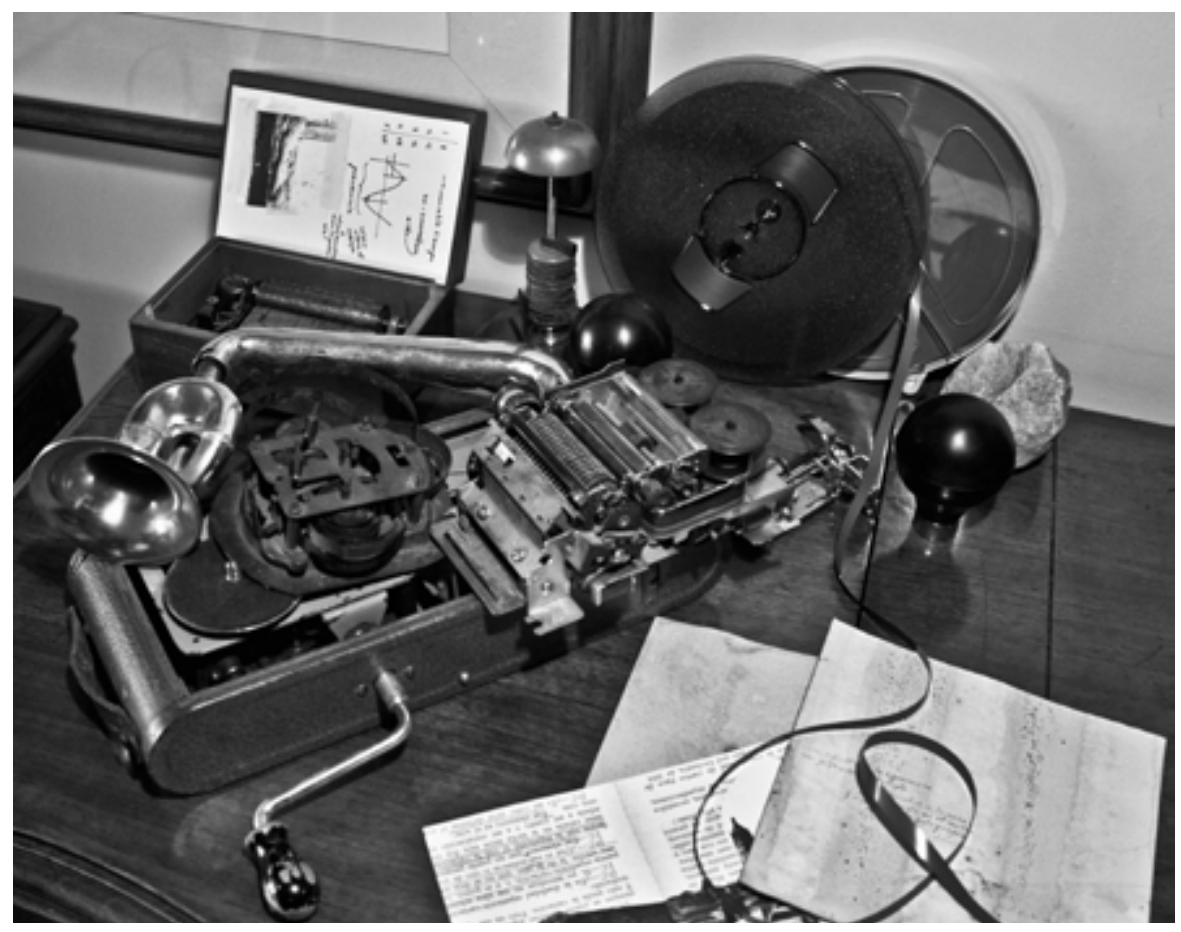

Figura 4. Carlos Mauricio Bejarano Calvo: El protofonógrafo.

Gracias a la amabilidad del dueño y curador del museo y en el marco del II Premio Bienal de Artes Plásticas y Visuales Bogotá 2012, realizado en la casa de la actual Fundación Gilberto Alzate Avendaño, se pudo instalar este sonido histórico. La obra llamada Estruendo se ubicó sobre el balcón principal de la casa y en el nicho interior de la ventana correspondiente. Cada estruendo, con una duración de un minuto y medio, sonó hacia la calle de la Fatiga y hacia el interior de la casa, todos los días durante el mes del evento, cada quince minutos entre largos silencios elocuentes. El trabajo de creación sonora consistió, en primera instancia, en la limpieza, edición y selección del material fonográfico encontrado, que luego fue sometido a un proceso de acumulación progresiva — capa a capa— hasta llegar a la producción de cuatro diferentes estruendos.

Unas semanas más tarde se realizó en Bogotá la 1. ${ }^{a}$ Semana del Sonido 2012 con el apoyo de la Fonoteca de la Radio Televisión Nacional de Colombia — hoy Señal Memoria- y de la Fonoteca Nacional de México. Siendo el tema de esta semana el sonido de la cotidianidad, fue pertinente recrear este ruidoso hecho histórico — los tiempos del ruido- con la obra Estrépitos. La palabra estrépito significa un ruido enorme y potente, un ruido de gran magnitud, un estruendo, ruido, fragor, clamor, bullicio, estridencia. La idea fue entonces proyectar este gran ruido en algunos entornos del contexto cotidiano bogotano. La obra consistió en una instalación e intervención urbana exclusivamente audible, con un estrépito de gran intensidad que afectó y alteró momentánea y sorpresivamente el transcurrir cotidiano de los transeúntes. El estrépito fue concebido con una duración de 4 min 33 s como un homenaje a John Cage (4'33'), quien precisamente en 2012 cumpliera veinte años de muerto, y particularmente el 5 de septiembre, durante la semana del sonido, cumpliría cien años de vida. Este estrépito se configuró a partir de los estruendos ya existentes y trabajados y se procedió a un nuevo proceso de acumulación que llegó a un sonido muy denso, complejo y francamente ruidoso. Estos estrépitos se instalaron en el espacio público de algunos lugares de Bogotá relacionados con 
los archivos, como la Biblioteca Nacional, el Archivo General de la Nación, el Museo Nacional de Colombia, la Biblioteca de El Tunal y el Teatro Jorge Eliécer Gaitán. En estos sitios, muy concurridos por transeúntes, sonó el estrépito con gran intensidad todos los días de la semana al mismo tiempo a las once de la mañana y a las cuatro de la tarde.

Tanto Estruendo como Estrépitos son piezas de arte sonoro y, en cierta medida, ejercicios de una arqueología sonora -imaginaria - en los que se reconstruye e instala plásticamente un fragmento de tiempo, una partícula sonora espacio-temporal... un pedazo de mundo, de historia, de memoria y de paisaje.

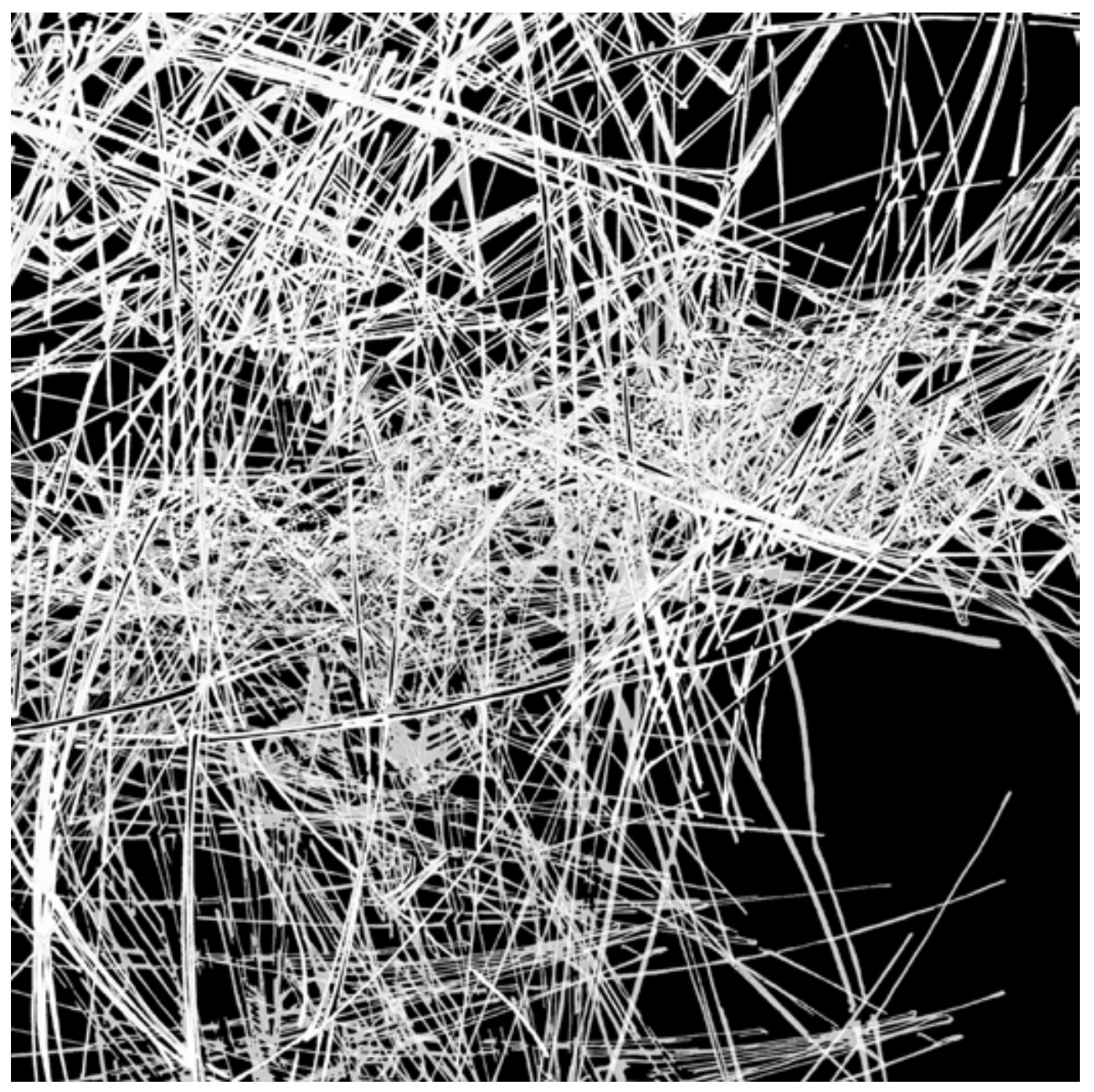

Figura 5. Carlos Mauricio Bejarano Calvo: Estrépitos, 2012. Grafía de un estrépito. 


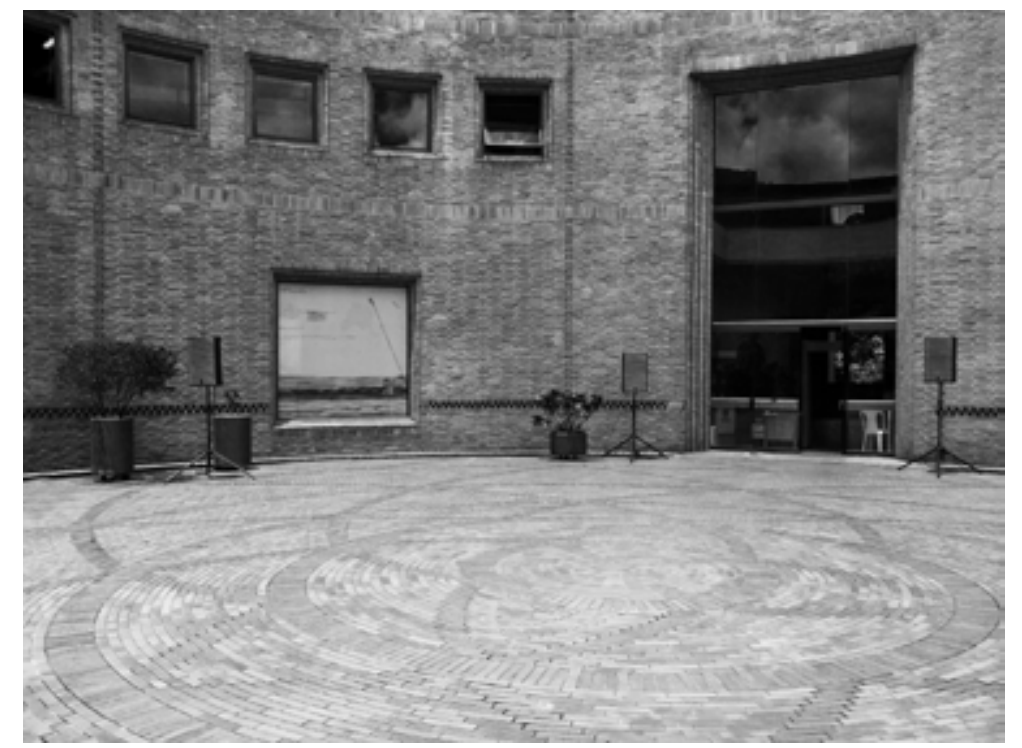

Figura 6. Carlos Mauricio Bejarano Calvo: Estrépitos, 2012.

Instalación en el patio del silencio del Archivo General de la Nación en Bogotá

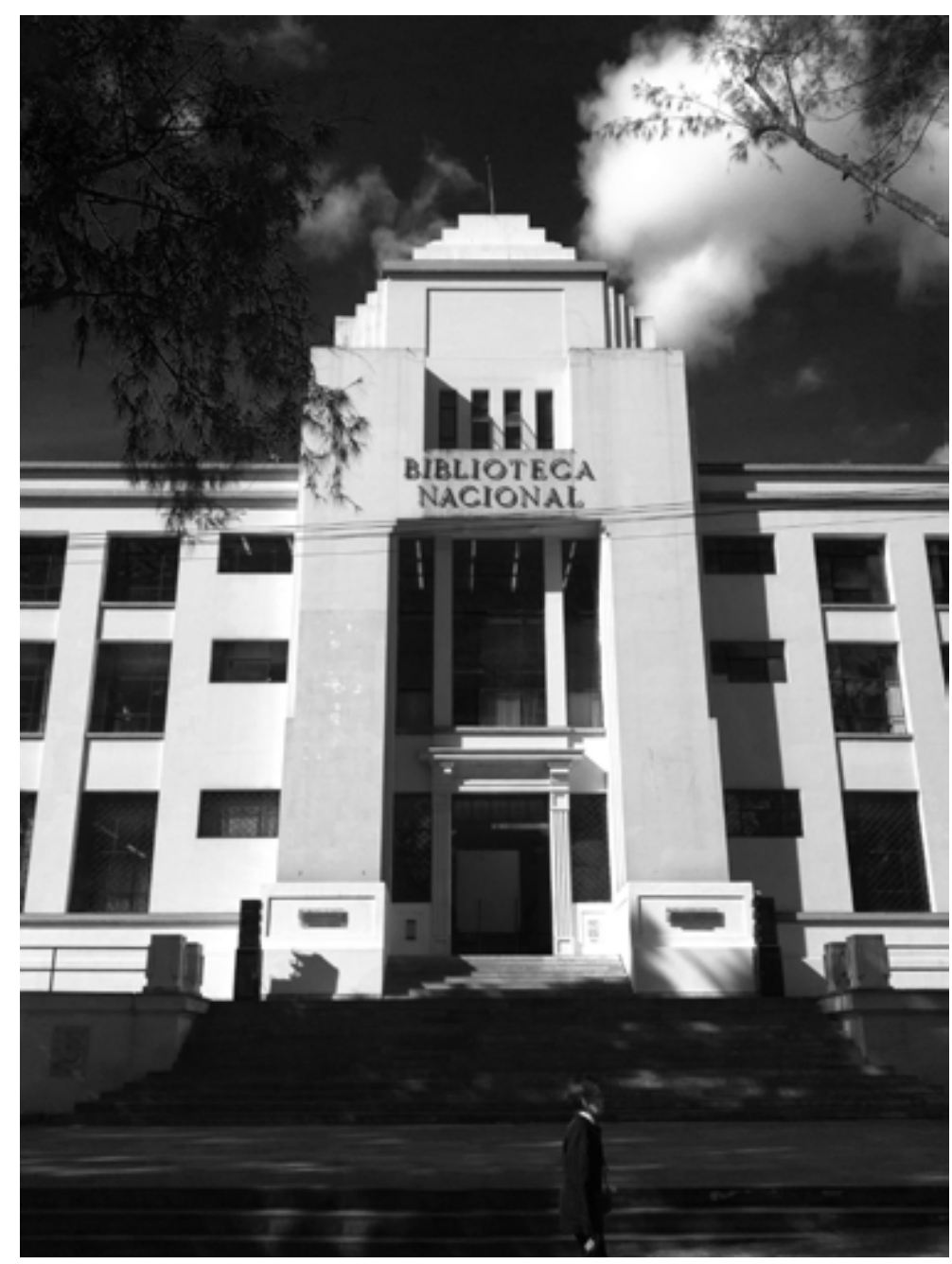

Figura 7. Carlos Mauricio Bejarano Calvo: Estrépitos, 2012. Instalación en la fachada de la Biblioteca Nacional en Bogotá. 


\section{RUMORES...}

Gracias a las invenciones, en las últimas décadas del siglo XIX y principios del XX, de los medios audiomecánicos y electroacústicos: fonografía, radiofonía, telefonía y fonosíntesis eléctrica, y a los desarrollos en tecnologías audionuméricas o digitales de la segunda mitad del siglo $X X$, el sonido y el ruido se han instalado con toda disponibilidad, intensa y cualitativamente en todos los ámbitos cotidianos y ordinarios de la vida. Hoy, los hemos asimilado como un renovado material y recurso artístico con un enorme potencial plástico avanzando en su comprensión y aprehensión sensorial y cultural y así se ha convertido en una materialidad dúctil y maleable.

La nueva música tenía que abrazar todos los ruidos de la edad mecánica, el ritmo de la máquina, el estrépito de la gran ciudad y de la fábrica, el zumbido de las correas de transmisión, el traqueteo de los motores y las estridentes notas de las bocinas. [...] Imitaban, pues, todos los sonidos concebibles de la industria y la tecnología, que unían en peculiares fugas, cargadas de un universo de ruido ensordecedor. La nueva "máquina de música" fue ampliando ámbitos para hacerse oír, y pronto se compusieron sinfonías de ruido, óperas de ruido y espectáculos festivos de ruido. ${ }^{1}$ (Fulop-Miller 1962, 183, 184)

En las tres primeras décadas del siglo XX, el futurismo soviético, o como también se le conoce cubofuturismo, productivismo ruso o proyeccionismo (en palabras de Solomón Nikritin que las define como las artes del futuro), produjo propuestas innovadoras respecto del ruido. En la poesía, se descubre un nuevo potencial en el ruido contenido en su propio sonido. Muchos creadores se sumaron a la búsqueda de la poesía sonora explorando el valor mismo de las expresiones de la voz que excluye toda referencia a la voz hablada, cantada o declamada; se crean innumerables poemas fonéticos que definen su valor intrínseco frente al predominio del verbo escrito. Nacen la música verbal que explora los ritmos repetitivos y las divisiones temporales, la verbofonía, el letrismo y la música letrista que logra la reconciliación entre música y poesía. Se inventan meganeumas, poemas expectorantes, sin verbo y sin semántica.

Otros movimientos en España e Iberoamérica, como el creacionismo, el ultraísmo o el estridentismo, dejaron rastros ruidosos interesantes, sobre todo, en el campo de la poesía sonora y lírica y, en alguna medida, en las artes plásticas y visuales. El estridentismo fue un movimiento que tomó gran parte de los ideales futuristas y acogió a artistas de diversas disciplinas que contextualizaron los conceptos de las vanguardias europeas a las condiciones del contexto local.

Ya nada de creacionismo, dadaísmo, paroxismo, expresionismo, sintetismo, imaginismo, suprematismo, cubismo, orfismo, etc., etc., de "ismos" más o menos teorizados y eficientes. Hagamos una síntesis quinta-esencial y depuradora de todas las tendencias florecidas en el plano máximo de nuestra moderna exaltación iluminada y epatante, no por un falso deseo conciliatorio, - sincretismo-, sino por una rigurosa convicción estética y de urgencia espiritual. (Maples 1921) 
En estos movimientos y tendencias, a través de sus diversos trabajos, se redescubren el sonido y el ruido, se revisa la noción misma del entorno sonoro que permite que los sonidos ordinarios de la vida se hagan cada vez más presentes y disponibles y se puedan valorar y utilizar como materialidad plástica y musical en su máximo potencial. Se trabaja con algunos medios tecnológicos que operan con el sonido, como el gramófono, la radiofonía y el cine sonoro asumidos como medios experimentales para la creación artística. Se concibe la radio como un arte con nuevas posibilidades expresivas liberadas de las tradiciones literarias y teatrales y la expresión radiofónica se abre a sus potenciales de simultaneidad espacial y temporal y a la utilización de ruidos. Las palabras descubren su libertad con la poesía sonora y el ruido asume su propia sonoridad.

Se opera directamente con los soportes y medios tecnológicos, como el cilindro de cera y el disco de vinilo, y se traza un camino sistemático para la experimentación y la reflexión en torno al sonido fijado y mediatizado; se estudian científicamente las minúsculas muescas que tienen los surcos de los registros fonográficos con el fin de saber qué formas gráficas corresponden a qué fenómenos sonoros para descubrir una lógica formal y así constituir una escritura acústica para producir nuevos sonidos. Asimismo, se estudian las imágenes del sonido del registro fonóptico del naciente cine sonoro para poder sintetizar el sonido partiendo de la invención misma de las grafías e imágenes visuales.

Al unísono con los movimientos experimentales y las vanguardias artísticas, se gestaron nuevos rumbos respecto de la percepción y el conocimiento del sonido, y de paso con respecto a la noción de paisaje sonoro, a las formas físicas de generarlo, estabilizarlo, transportarlo y transformarlo, al igual que en su manejo expresivo en diferentes terrenos de la creación, como la música, la poesía, el cine y las artes plásticas.

El sonido y su paisaje, como nuevas materialidades, se nos presentan de manera abierta y totalmente disponibles. El sonido es un objeto tan a la mano que las preocupaciones en torno a su cuantificación y a su relación con estructuras exactas pierde importancia para cederle paso a la experimentación directa, sensible y gestual sin representaciones previas y abstractas... el objeto sonoro, el sonido objeto, el ruido, ahí a la mano, posible, escueto, crudo, factible y desnudo.

\section{DOS TRUENOS}

Trueno es una palabra sonora que estalla en el cielo y que significa estruendo asociado al rayo producido en las nubes por una descarga eléctrica.

La semana pasada leí un texto [...] titulado "Ec cco", en el cual suena un trueno muy similar al que cayó en Finnegans Wake de James Joyce. Ambos truenos tienen 100 letras y ambos cayeron con signos de exclamación. La única diferencia está en el idioma. Mientras el trueno de Joyce está escrito en lenguas europeas, el trueno de Ec cco sonó en lenguas andinas y sus letras están distribuidas de la siguiente manera:

IluuiivvilliplliynnnfallallallayLliplliyllipipipiynnaayllapawaklinnnwakkllinnnmmmhhbururunyaaytrwinu 
Murray Schafer, en su libro Cuando las palabras cantan, publicado en 1970, analiza la palabratrueno de James Joyce. En esta oportunidad, mi intención es compartir con ustedes el análisis [...] de la palabra-trueno-andino, caída por primera vez desde el cielo boliviano en 1900, en la tradición oral de la comunidad de los Uros, en el lago Titicaca. La palabra volvió a aparecer el 16 de abril de 2013 en Ec cco, como si su voz se hubiera dilatado en el tiempo. Nótese que el trueno cayó primero en Suramérica y luego en París el 4 de mayo de 1939, este último probablemente traducido a lenguas europeas.

El trueno andino contiene la palabra trueno escrita solo en quechua. [...]

Lo más bello y curioso de esta palabra aparece cuando se lee en castellano, ya que así el trueno suena como la lluvia: "Iluuiivvilli". (Bejarano 2012, 72, 73)

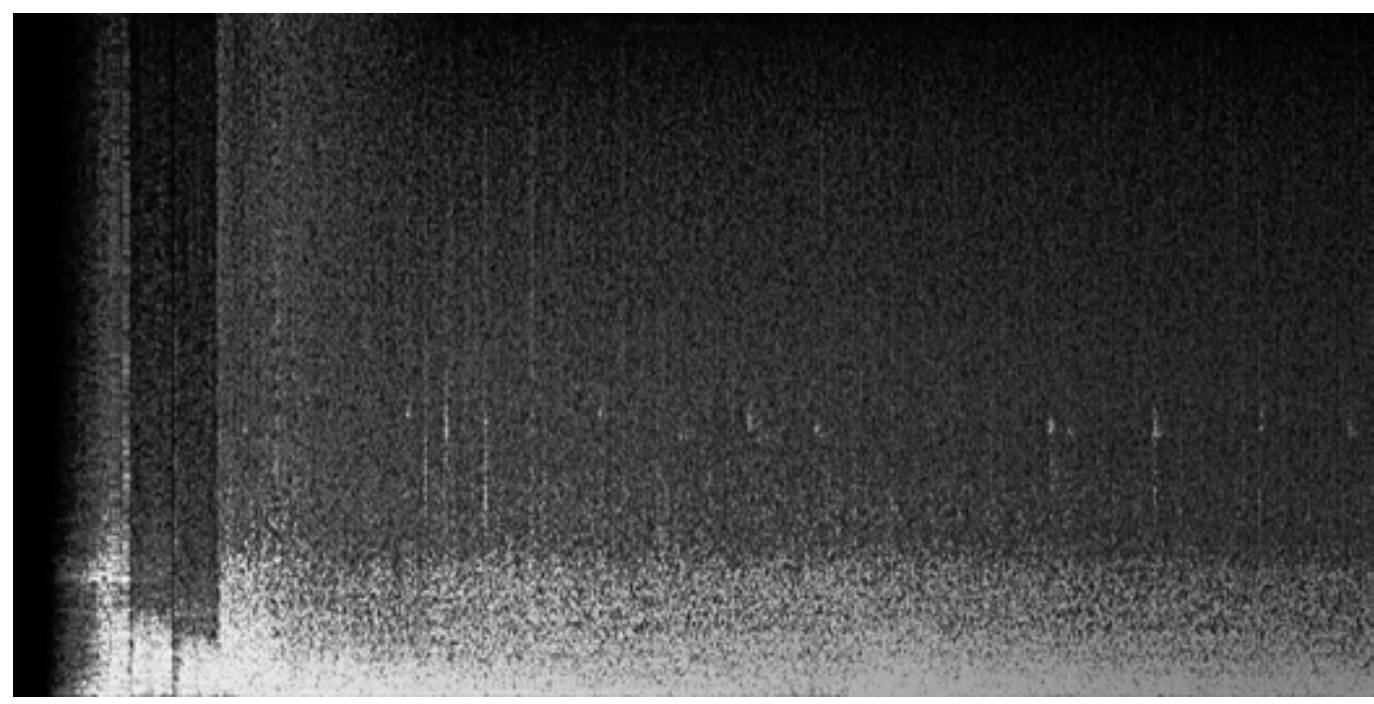

Figura 8. Carlos Mauricio Bejarano Calvo: Otros truenos... Fonograma (fragmento inicial) de Vapor de trueno gris.

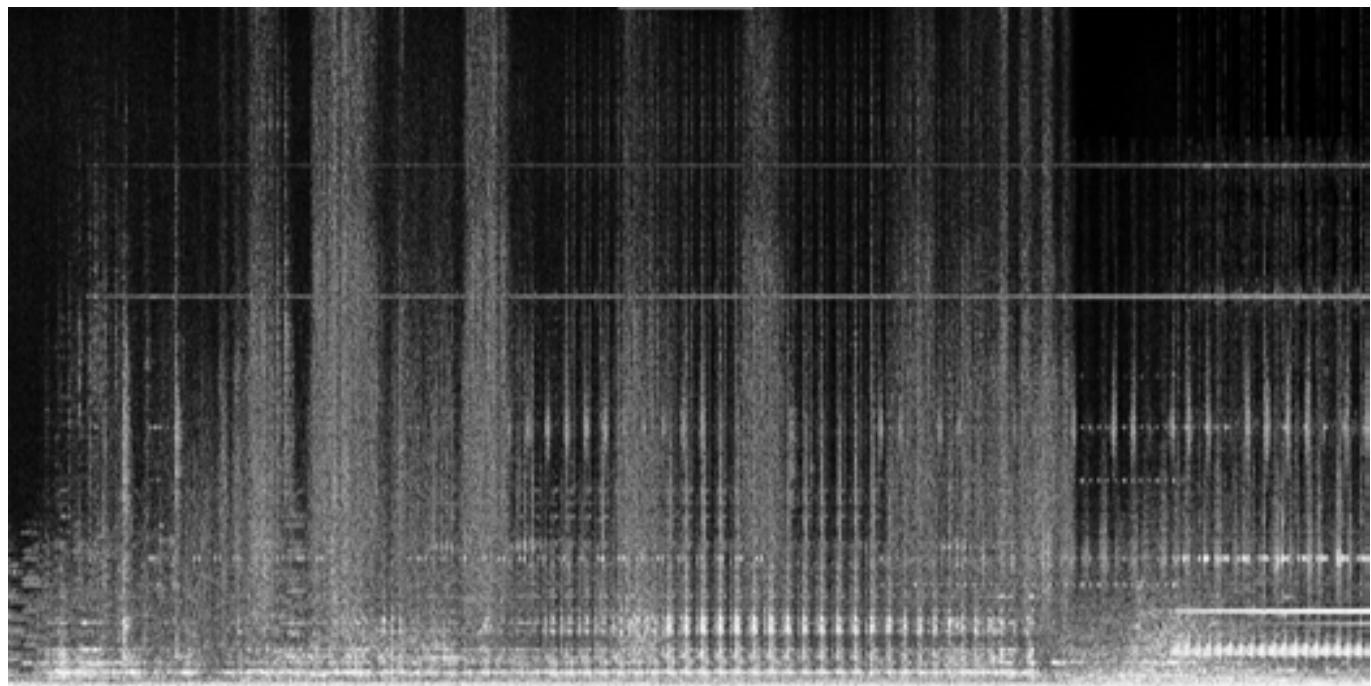

Figura 9. Carlos Mauricio Bejarano Calvo: Otros truenos... Fonograma (fragmento rítmico) de Vapor de trueno gris. 


\section{“VAPOR DE TRUENO GRIS"}

Vapor de trueno gris (Bejarano 2014) es una escultura sonora, frontal y cinematofónica, es un intento leve de crear este sonido objeto llamado trueno. Partiendo del sonido del trueno, los trazos y las texturas revelan un potente movimiento morfológico interior. Se genera una especie de efervescencia sonora que se instala al frente del espectador como un potente muro que proyecta un gas envolvente que ocupa el volumen de la escucha. Estrépitos, fragores y truenos navegan en un periplo continuo y se sumergen en un vapor resonante donde la materia sonora se desplaza dentro de un mismo fluido, flotando, hasta llegar a desdibujar sus contornos. Densas texturas se dispersan, se hacen lisas, delgadas, transparentes y afiladas; eventos desencadenados, frotaciones y acumulaciones en nubes, en ráfagas, en tramas sonoras; masas que se ciernen, se pulverizan y se evaporan. En cierto momento, hacia el final de estos 34 min de escucha intensa, emergen tambores y ritmos — seudotecno y seudotranceque evocan ese poder palpitante de los ciclos de la vida.

\section{“TRUENO 88:8"}

De manera similar a la anterior obra, en TRUENO 88:8, que es una composición de música acusmática, proyectada mediante un dispositivo octofónico —ocho canales- que rodea al público y lo envuelve en una inmersión total, un conjunto de estrépitos, estruendos y truenos, como si fuesen objetos plásticos, navegan en un discurrir incesante y se sumergen en un mar denso de vapor resonante donde la materia sonora rugosa, opaca y cruda se desplaza en el interior de un mismo fluido, como ondeando, casi estática, hasta llegar a desintegrar sus cualidades morfológicas, materiales y físicas.

En algunas ocasiones se escuchaban los sonidos melancólicos de su órgano [piano] que tocaba con mucha expresión, pero de noche solamente, en medio de la oscuridad más secreta, cuando el Nautilus parecía dormirse en los desiertos del océano. (Verne 1961, t. 2, 100)

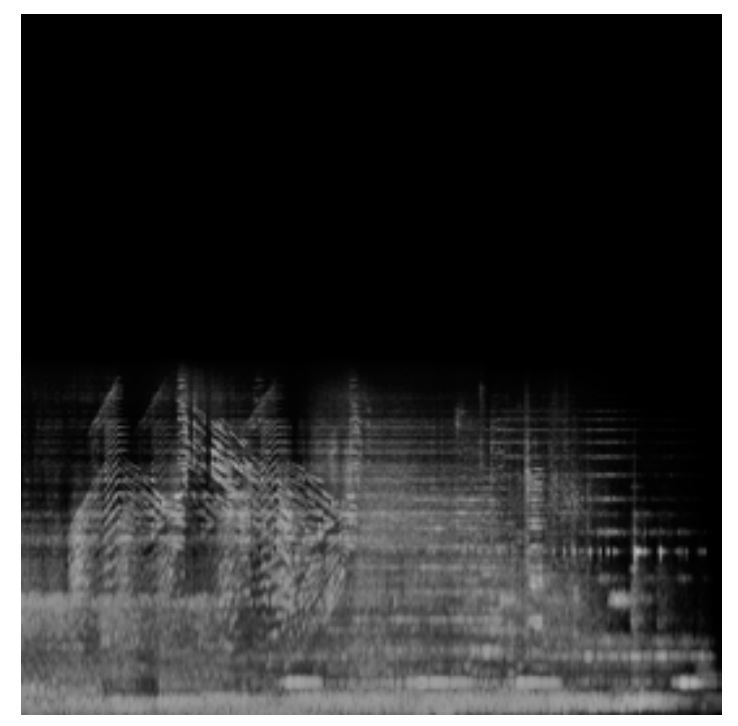

Figura 10.

Carlos Mauricio Bejarano Calvo: TRUENO 88:8, 2014 Fonograma (fragmento). 


\section{¡SIEMPRE HABRÁ UN SONIDO MÁS!}

La promesa de un mundo menos ruidoso, como consecuencia del paso de las tecnologías duras, pesadas, mecánicas y metálicas de la revolución industrial de los siglos XVIII y XIX a las tecnologías blandas y silenciosas de la revolución eléctrica, electrónica y digital, no fue posible. Por el contrario, nos encontramos ante un mundo donde la omnipresencia del sonido -registrado, fragmentado, diversificado, multiplicado, modulado, reproducido y amplificado- se manifiesta en todos los rincones del mundo, en cada instancia y momento de la vida cotidiana humana; el sonido en nuestros cajones, en nuestros bolsos y bolsillos, en nuestras manos y oídos, se ha convertido en un objeto absolutamente ordinario y común.

Estamos expuestos en todos los ambientes cotidianos a sonidos que emanan desde innumerables dispositivos (altoparlantes de todo tipo), estamos en permanente contacto con soportes y medios que lo almacenan, archivan, transportan, manipulan y proyectan. Como una consecuencia de las tecnologías electroacústicas y audionuméricas, además de su inherente condición esquizofónica, el sonido separado de sus causas (Schafer), nuestro entorno se ha convertido en un permanente continuo de sonidos, inacabado y complejo y así ha contribuido a disolver los límites entre materia, espacio y tiempo real, y materia, espacio y tiempo diferido. Tenemos ante nosotros un inmenso horizonte de posibilidades expresivas que utilizan el sonido con estos nuevos potenciales instrumentales, materiales, sensibles y morfológicos.

Una de las condiciones tecnológicas recientes que ha afectado de manera contundente el sonido y su percepción ha sido la amplificación eléctrica. Hoy contamos con medios electroacústicos que permiten aumentar la potencia de cualquier sonido, por leve que este sea, y agrandar a discreción su tamaño, sus contornos dinámicos y lograr una escucha sorprendente y literalmente inaudita. Es cierto que la amplificación, combinada con la sonofijación, ha hecho de nuestro entorno sonoro un mundo sin pausa, continuo, inacabado, envolvente $y$, muchas veces, ensordecedor y contaminante; y cada vez más parece imposible encontrar en el planeta momentos y lugares donde aún se puedan escuchar los silencios y las transparencias del mundo, silencios elocuentes llenos de vida y misterio.

Claro que si pensamos y actuamos como creadores sonoros o como compositores de música electroacústica (que incluye aquí las músicas concreta, electrónica, acusmática, experimental y algunas modalidades del arte sonoro), y asumimos artísticamente la condición de la amplificación y de su opuesto la desamplificación, las encontraremos maravillosas y con unas posibilidades increíbles. Con este simple recurso, podremos escuchar sonidos sutiles, tal vez algunos de ellos inaudibles, y paradójicamente, al trabajar con sonidos muy potentes como el trueno, tendremos la capacidad de darle una nueva dimensión expresiva y duplicar o quintuplicar su potencia, o a la inversa, atenuándolo casi silenciándolo, hasta llevarlo a los límites más extremos de la percepción.

Con estas nuevas condiciones, el sonido y el ruido, como materialidades plásticas, se han visto afectados en su más íntima y esencial contextura, en las maneras de percibirlos y conocerlos, sufriendo fuertes cambios en sus potenciales expresivos. El sonido adquiere un valor material inédito: es observable al micrófono y al computador; podemos memorizarlo y fijarlo en soportes, es maleable, transportable y reproducible; es posible sintetizarlo íntegramente y amplificar sus detalles hasta llevarlo a extremos de sutiles y dramáticas intensidades. 
Las preocupaciones artísticas en torno al sonido se han desplazado de sus territorios tradicionales, como la música y el lenguaje, para instalarse en nuevos espacios y terrenos de las artes plásticas y experimentales. Las nuevas posibilidades de transmisión del sonido nos permiten pasar de un sonido causado y percibido en un espacio y lugar único, directo, real y corporal a un sonido mediatizado, proyectado y amplificado en un espacio múltiple, diferido y virtual. El sonido, además de poder ser instalado físicamente en soportes estables, es posible transformarlo o generarlo de manera sintética y producir un infinito repertorio inédito e inaudito. Podemos crearlo artificialmente, separado de sus condiciones causales, sin referencias a sonidos conocidos por el lenguaje, la música o la vida cotidiana; hemos logrado estabilizarlo, manipularlo a gusto, auscultarlo con fino detalle... es a la vez sintético y abstracto, tangible y evanescente, objetual y sólido.

Desde comienzos del siglo XX, el sonido se ha instalado en el ámbito de las artes plásticas que lo ha manejado como una materialidad con potenciales expresivos en sí mismo. Aparecen modalidades de creación puramente sonoras, derivadas de los desarrollos estéticos e instrumentales de los medios electroacústicos, como el arte sonoro electroacústico y el arte acusmático, presentes en distintas modalidades formales, como instalaciones sonoras (generativas, interactivas o reactivas), formatos autocontenidos (sonido memorizado y fijado en soportes), esculturas, objetos, acciones e intervenciones sonoras, arte radiofónico, así como en el registro, la documentación y la recreación de paisajes sonoros, entre muchas otras.

La escucha pura es privilegiada, se refina y se amplía hacia insospechados, inauditos e inéditos repertorios. El sonido se instrumentó y mediatizó de manera fundamental y definitiva. Hemos llegado a la máxima libertad y disponibilidad del sonido. Se han inundado los escenarios del mundo y de la vida cotidiana con innumerables e inefables sonoridades; se han habitado y colonizado todos y cada uno de sus lugares, y por su hálito envolvente, se ha implicado perceptivamente una noción total del entorno y no un solo fragmento escénico y frontal, la escucha se ha extendido en la concavidad sorda del mundo. El sonido se ha separado de su dimensión estrictamente física, de sus hechos causales, ha sido arrancado de los cuerpos anatómicos y mecánicos que lo producen, se han amputado los eventos corporales y las imágenes sonoras fluyen acumulándose por todos lados, tamizando y disponiendo el medio a través del simulacro, rompiéndose y abriéndose la geografía hacia nuevos e insospechados ámbitos. Nos hemos instalado dentro del sonido en su contextura más ínfima e íntima... en sus más mínimas inflexiones y detalles. Auscultamos todo, ponemos todos los cuerpos y las cosas a vibrar haciéndolos sonar; intervenimos los paisajes sonoros, los transportamos, manipulamos y escuchamos con extrema libertad e interactuamos abiertamente con todas sus características morfológicas. Este sonido, altamente mediatizado, amplía y diversifica la posibilidad de fundar y construir espacios, lugares y silencios; lugares de memoria (y también no lugares con sonidos intrusos); podemos afectarlos, caracterizarlos, intervenirlos y transformarlos. Fundamos lugares sonoros inauditos e inéditos; sembramos, cultivamos y conservamos infinidad de especies sonoras.

La oreja parece hecha para la captura del indicio que pasa: es inmóvil, está clavada, tiesa como un animal al asecho; recibe el máximo de impresiones y las canaliza hacia un centro de vigilancia, selección y decisión; los pliegues, las revueltas, de su pabellón parecen querer multiplicar el contacto entre el individuo y el mundo y, sin embargo también reducen esta multiplicidad sometiéndola a un recorrido ya elegido; pues es necesario —en eso reside el papel de esta primera escucha- que lo que era confuso e indiferente se vuelva distinto y pertinente. (Barthes 2009, 280) 
Tenemos, entonces, necesariamente que educar y educarnos poniendo mayor énfasis en una escucha creativa, sensitiva y consciente, minuciosa y sutil, lúcida y lúdica, con la posibilidad de proponer sobre nuestros más comunes y ordinarios entornos públicos y privados, de colorear de climas, de vibraciones y de fragancias sonoras nuestra vida y nuestros paisajes cotidianos.

Así, el trueno siempre ha estado presente en el quehacer cotidiano y emerge como un hecho contundente que marca drásticamente nuestra vida y nuestros paisajes. El sonido del trueno, potente y amenazante, ha acompañado nuestra existencia desde tiempos inmemoriales en cualquier lugar, en todos los resquicios del planeta y en cualquier momento o instante de la cotidianidad. Además, el sonido del trueno ha sido parte fundamental de la práctica artística personal reciente en los campos de la música concreta y el arte sonoro.

Inconmensurable y lleno de posibilidades plásticas, musicales y morfológicas, siempre asociado a los poderes de la creación y la fuerza primigenia del mundo, el sonido del trueno es un objeto disponible que ha sido asiduamente utilizado en las representaciones teatrales, en las narraciones literarias, en las composiciones musicales, en las experimentaciones de las músicas actuales y en las diversas y recientes manifestaciones del arte sonoro y así ha exaltado el deseo y el gusto de crear y experimentar con esta compleja, potente y significativa materialidad sonora. 


\section{REFERENCIAS}

Andrés, Ramón. 2012. Diccionario de música, mitología, magia y religión. Barcelona: Acantilado.

Attali, Jacques. 1996. Ruidos, ensayo sobre la economía política de la música. México: Siglo XXI.

Barthes, Roland. 2009. Lo obvio y lo obtuso: imágenes, gestos, voces. Barcelona: Paidós.

Bejarano Calvo, Carlos Mauricio. 2012. Estruendos. Instalación audible. Bogotá: Fundación Gilberto Alzate Avendaño, acceso 2 de agosto de 2017, https://goo.gl/NE8qYr

Bejarano Calvo, Carlos Mauricio. 2012. Estrépitos. Instalación sonora en el espacio urbano. Bogotá: Archivo General de la Nación, Museo Nacional, Biblioteca Pública El Tunal, Biblioteca Nacional y Teatro Jorge Eliécer Gaitán, acceso 2 de agosto de 2017, https://goo.gl/oaZQQN

Bejarano Calvo, Carlos Mauricio. 2013. Tres sonidos. Estreno de la obra para percusión y electrónica interpretada por Federico Demmer. Bogotá: Biblioteca Nacional, Auditorio Germán Arciniegas.

Bejarano Calvo, Carlos Mauricio. 2014a. TRUENO 88:8. Obra octofónica (ocho canales). Concierto AKUSMATIKON. TaPeTe, auditorio de conDiT (conciertos del Distrito Tecnológico Buenos Aires), edificio de cheLA (iniciativa de la Fundación ExACTa y el Programa de Culturas Digitales de la Universidad de California). cheLA - Iguazú 451- CABA, Buenos Aires.

Bejarano Calvo, Carlos Mauricio. 2014b. Vapor de trueno gris/2014/34:00. Instalación sonora frontal con 12 parlantes. Manizales: Teatro Los Fundadores, acceso 2 de agosto de 2017, https://goo.gl/7WE9hF

Bejarano Calvo, Carlos Mauricio. 2015. Auscultare II: arte sonoro 2009/2014. 2 CD + libro. Bogotá: Universidad Nacional de Colombia.

Bejarano, Sebastián. 2012. Tartamudo. Bogotá: Animal Extinto.

Bergerac, Cyrano de. 1987. El otro mundo: los estados e imperios de la luna. Madrid: Anaya.

Fulop-Miller, René. 1962. The Mind and Face of Bolshevism. Nueva York: Harper \& Row.

Joyce, James. 1993. Finnegan's Wake. Barcelona: Blume.

Maples Arce, Manuel. 1921. +Actual nº 1. Xalapa, México.

Moreno Cardonas, Freddy. 2008. "Traducción del reporte original del ruido escuchado en Santafé de Bogotá el domingo 9 de marzo de 1687." El Astrolabio 84-90.

Moreux, Serge. 1950. Primer concierto de ruidos. París: Escuela Normal de Música.

Ronnberg, A. y Martin, K., eds. 2011. El libro de los símbolos: reflexiones sobre las imágenes arquetípicas. Taschen.

Russolo, Luigi. 1916/1998. El arte de los ruidos: manifiesto futurista. Ciudad Real, España: Universidad de Castilla-La Mancha.

Verne, Jules. 1961. 20.000 leguas de viaje submarino. Madrid: Plaza \& Janés.

Voltaire. "Diccionario filosófico", acceso el 8 de agosto de 2017,

http://www.e-torredebabel.com/Biblioteca/Noltaire/cielo-antiguos-Diccionario-Filosofico.htm

\section{Cómo citar este artículo:}

Bejarano Calvo, Carlos Mauricio. 2017. “Truenos: ruidos, sonidos y modos de escucha en la creación sonora". Cuadernos de Música, Artes Visuales y Artes Escénicas. 12 (2): 187-209. https://doi.org/10.11144/javeriana. mavae12-2. trsm 